\title{
Nutritional evaluation of butter prepared from fresh adulterants free cow milk
}

\author{
Sabiha Rashid ${ }^{1}$, Amina Arif ${ }^{1 *}$, Abdul Majeed Salariya ${ }^{2}$, Muhammad \\ Uzman Raza ${ }^{2}$, Shabana Kausar ${ }^{3}$, Mushtaq Ahmad Saleem ${ }^{1}$ and Javed \\ Iqbal Wattoo ${ }^{1}$ \\ 1. University of Central Punjab, Lahore-Pakistan \\ 2. University of Education, Township Campus, Lahore-Pakistan \\ 3. The Pakistan Council of Scientific and Industrial Research (PCSIR) Complex, Lahore-Pakistan \\ *Corresponding author's email: amina.arif@ucp.edu.pk \\ Sabiha Rashid, Amina Arif, Abdul Majeed Salariya, Muhammad Uzman Raza, Shabana Kausar, Mushtaq \\ Ahmad Saleem and Javed Iqbal Wattoo. Nutritional evaluation of butter prepared from fresh adulterants free \\ cow milk. Pure and Applied Biology. Vol. 6, Issue 4, pp1366-1371.
}

http://dx.doi.org/10.19045/bspab.2017.600147

\begin{tabular}{llll}
\hline \hline Received: 21/08/2017 & Revised: 10/10/2017 & Accepted: 14/10/2017 & Online First: 26/10/2017 \\
\hline \hline
\end{tabular}

\section{Abstract}

This study was performed for the nutritional evaluation of butter prepared from cow's milk free of adulterants. Fresh cow's milk was analysed for various physico-chemical parameters such as detergents, urea, sugar, starch, glucose, sorbitol, hydrogen peroxide, formalin and salts. The cream was prepared from the milk, which by a conventional method of stirring transformed to the butter. Butter was divided into four parts in separate containers already having different concentrations of sodium chloride as the preservative. One sample was kept as blank while the remainder of the three samples contained respectively $0.5,1.0$ and $2.0 \%$ sodium chloride. The chemical composition of the butter samples was determined by analyzing the percentage of moisture, ash, total protein and fat. All butter samples were stored under refrigeration at $12^{\circ}$ C. The development of rancidity was studied for almost two months. Refrigeration and sodium chloride as a preservative played an important role in preventing the development of rancidity in butter. The quality assessment report showed that the unsalted butter sample was not saturated at a temperature of $12^{\circ} \mathrm{C}$ for almost six weeks and salted butter samples with 1.0 and $2.0 \%$ sodium chloride were not staled for more than two months. Therefore it was concluded that for long term consumption, butter must be kept at $12{ }^{\circ} \mathrm{C}$ and could be preserved using at least $1 \%$ sodium chloride.

Keywords: Milk; Butter; Adulterants; Rancidity; Peroxide-value

\section{Introduction}

Butter is smooth, light yellow, reasonably firm but still easily spreadable mass, which mainly consists of milk-fats and water. The product butter has been reported since man started drinking milk. From archaeological findings, it was confirmed that the ancient Persians and the ancient Egyptians used to use butter. The Greeks and Romans also knew butter as a base of ointments and beauty-aids. Nutritional aspects of milk and milk products have been under investigation since that time [1]. Butter is conventionally and commercially prepared from milk in different areas of Pakistan but butter-fats spoil rapidly and easily. The addition of salt to butter inhibits growth of some microorganisms and kills others, so 
keeping quality of salted butter better than that of unsalted. Butter have relatively short life unless it is stored at low temperature. Frozen butter can be kept for some months without serious deterioration in flavour [2]. Samples containing Enterobacter aerogenes and Citrobacter freundii Upases exhibited rancidity even after 18 days of storage. Yersinia enterocolitica lipase showed rancidity after 14 days of storage at $7{ }^{\circ} \mathrm{C}$. [3]. Exposure of butter and butter fat to high temperatures, light and air did not cause a marked change in the iodine numbers and this exposure did not cause rancidity [4]. An intramural aerobic mycological examination was performed, which included eight locations in dairy products with a Burkard volumetric individual air sampler. The equipment was cold storage $(-2)$, a cold central section $\left(8^{\circ}\right.$ $\mathrm{C})$, a conditioning section $\left(23^{\circ} \mathrm{C}\right)$, a milk processing section $\left(24^{\circ} \mathrm{C}\right)$, a quality control reconstruction Milk $\left(25^{\circ} \mathrm{C}\right)$, storage of raw milk $\left(28^{\circ} \mathrm{C}\right)$ and a loading dock $\left(26^{\circ} \mathrm{C}\right)$. The highest spore quantity was recorded in the packaging section $\left(23^{\circ} \mathrm{C}\right)$ and the minimum in the butter cold store $\left(-2^{\circ} \mathrm{C}\right)$ [5]. Then investigated the profile of microbiological quality of butter during storage at $6-8{ }^{\circ} \mathrm{C}$ The microbial population of these products appeared to be on the upper side and the same increase during storage. The study found that a poor shelf life deteriorates the bacteriological quality of the product [6]. Samples of fresh butter were exposed to gamma irradiation at doses of $0,2.5$ and $5 \mathrm{kGy}$, followed by refrigerated storage. The effect of these treatments on the microbiological aspects and the lipid characteristics of the butter samples was studied. The present study demonstrated that 2.5 and $5 \mathrm{kGy}$ gamma irradiation doses kept quality of cows butter up and increased its shelf-life at $4 \pm 1^{\circ} \mathrm{C}$ for 8 and 12 weeks as compare to 4 weeks for the non-irradiated butter (based on the visual appearance of mold growth on the surface of sample) without any effects on its sensory properties [7]. The volatile fractions of the butter were stored at three different temperatures to control the quality during commercial shelf life (90 days). Two different extractions were compared, i.e the dynamic head space (purge and trap) and static head space (micro-SPME extraction in solid phase). Despite the various performances, both methods detected useful volatiles to evaluate changes during storage [8]. The antioxidant effects of propolis extracts in butter stored at $5^{\circ} \mathrm{C}$ and $25^{\circ} \mathrm{C}$ were tested. Different concentrations of propolis extract at $5^{\circ} \mathrm{C}$ were effective in retarding oxidation compared to the control [9]. The effects of extracts of oregano (Origanum vulgare) and sage (Salvia fruticosa) on the microbiological quality of butter were studied. Extracts and their combinations were individually added to the butter at 0.1 or $0.3 \%(\mathrm{w} / \mathrm{w})$ concentrations. For comparison, $0.2 \%(\mathrm{w} / \mathrm{w})$ of sorbic acid was used. The samples were stored at about 20 ${ }^{\circ} \mathrm{C}$ for 4 weeks. Herbal extracts and their combination exhibited antimicrobial effects on butter, but their antimicrobial activities were lower than sorbic acid [10]. The addition of EPO and butter phytosterols seems to alter their sensory properties, especially in terms of rancidity and general acceptability [11]. The effects of the antioxidants on the stability to the oxidation of butter under different time and the temperature of storage were studied. Natural (alpha-tocopherol) and artificial antioxidants (BHA and BHT) were added to the butter samples at two concentrations (50 and 100 ppm) immediately after obtaining the butter samples from pasteurized sweet cream. Then they were kept in the dark at $4{ }^{\circ} \mathrm{C}$ and $20^{\circ} \mathrm{C}$ for 6 months. The synthetic and natural antioxidants used were able to protect 
butter samples from oxidation during storage at both temperatures. Butter sample with 50-ppm antioxidants was stored for more than 180 days at $4^{\circ} \mathrm{C}$ without deterioration [12].

\section{Materials and methods}

Milk, the major raw material for the preparation of butter free from adulterants was purchased directly from the animal farm situated at Khanqah Dogran, Sheikhupura. Chemical analysis of raw cow milk was performed for the presence of various types of adulterants.

\section{Processing of butter}

Cream was used for the production of butter. After confirming purity of the milk, butter was processed by conventional churning method from the cream of the same milk.

\section{Flowsheet diagram Cream \\ Churning Action \\ $\downarrow$ \\ Buttermilk Separation

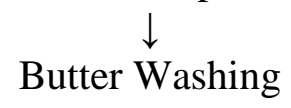

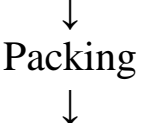 \\ Cold Storage $\left(12^{\circ} \mathrm{C}\right)$}

This butter was divided into four different samples for different treatments. Sample A served as control whereas $\mathrm{B}, \mathrm{C}$ and $\mathrm{D}$ contained $0.5,1.0$, and 2.0 percent of sodium chloride as preservative.

\section{Physico-chemical analysis of butter}

Different Physico-chemical parameters such as moisturizer, ash, fat, total solids and protein in all prepared butter samples were estimated by the methods as described in AOAC (Association of Official Analytical Chemists 2005) [13-16].

The development of rancidity was also determined using peroxide determination method [17]. In the fats impending deterioration taste was because of the presence of some rather unflavored components including peroxides and hydro peroxides. The initial stages of rancidity occurring under specific environmental conditions was straightforwardly measureable applying the peroxide value that was expressed as milli equivalent peroxide per $\mathrm{kg}$ sample. For the rancidity measurement, the samples were prepared by dissolving oil or fat in a particular solution of acetic acid in chloroform 3:2 $(\mathrm{V} / \mathrm{V})$. The solvent was evaporated under nitrogen and used for analysis. In this research, methods based on iodimetric titration were used. In these methods, the reaction of iodide with peroxides present in the oil, released iodine that was indirectly evaluated in a biphasic system with a thiosulfate solution. Working principle behind the iodimetric procedure involved the addition of iodine to unsaturated fatty acid double bonds. Addition of iodine to the double bonds is sensitive to the structure and reactivity of the peroxides and dependent on the temperature and time of the reaction [18].

\section{Results and discussion}

The milk used for butter processing was free of adulterants. The chemical tests were performed to determine the purity level of milk, which was used for the preparation of butter. Butter should be free of any adulterants to determine the exact nutritional and peroxide values. These test included the neutralizers, sugar, starch, urea, glucose, sorbitol, formalin, salts and hydrogen peroxide in raw cow milk. The results are shown in table 1. All the chemical tests indicated negative results showing that the raw cow milk is free of any type of adulterants and is fresh, hence perfect for further processing.

\section{Physico-chemical analysis}

Different physico-chemical characteristics of the butter obtained from above adulterants free milk were analysed. The results are shown in Table 2 . The moisture contents decreased from sample A $(15.36 \%)$ (Which was without sodium chloride preservative) to sample D (14.15\%) with $2.0 \%$ sodium chloride as preservative that has the ability to absorb 
water. On the other hand, the ash contents increased from sample A to D (1.02 $1.93 \%)$. The ash contents of the butter increased because sodium chloride itself contributed to ash. Similarly, the total solid contents were also increased from A to D $(84.64-85.85 \%)$ due to increasing percentage of sodium chloride in sample A to $\mathrm{D}$. The finding of butter composition for protein $(2.55 \%)$ and fat $(82.4 \%)$ contents of all the samples with different percentages of sodium chloride remained almost same because sodium chloride as preservative prevented them from being denatured. Recently similar research was conducted in India where they developed a methodology for detection of adulteration in cow ghee with Vanaspati by using image analysis technique along with the colour measurement [19].

Table 1. Milk adulteration tests

\begin{tabular}{|c|c|c|c|}
\hline Sr. No. & Tests & Response & Outcomes \\
\hline 1 & Detergents Test & Precipitation occurred & Negative \\
\hline 2 & Alcohol Precipitation Test & No Precipitation occurred & Negative \\
\hline 3 & Urea Test & No pink color & Negative \\
\hline 4 & Sugar Test & No green color & Negative \\
\hline 5 & Starch Test & No black pigmentation & Negative \\
\hline 6 & Glucose Test & Strip color not changed & Negative \\
\hline 7 & Sorbitol Test & Not sticky with test tube & Negative \\
\hline 8 & Hydrogen Peroxide Test & No blue color & Negative \\
\hline 9 & Formalin Test & No blue color & Negative \\
\hline 10 & Salt Test & Chocolate color & Negative \\
\hline
\end{tabular}

Table 2. Composition of prepared butter samples

\begin{tabular}{|c|c|c|c|c|}
\hline Parameters & Samples & NaCl added & Outcomes & Percentage \\
\hline Moisture & A & $0.0 \%$ & 0.768 & $15.36 \%$ \\
\hline & B & $0.5 \%$ & 0.760 & $15.21 \%$ \\
\hline & C & $1.0 \%$ & 0.718 & $14.36 \%$ \\
\hline & D & $2.0 \%$ & 0.705 & $14.15 \%$ \\
\hline Ash & A & $0.0 \%$ & 0.051 & $1.02 \%$ \\
\hline & B & $0.5 \%$ & 0.561 & $1.108 \%$ \\
\hline & C & $1.0 \%$ & 0.0932 & $1.864 \%$ \\
\hline Total Solids & D & $2.0 \%$ & 0.0965 & $1.93 \%$ \\
\hline & A & $0.0 \%$ & 4.232 & $84.64 \%$ \\
\hline & B & $0.5 \%$ & 4.239 & $84.79 \%$ \\
\hline & C & $1.0 \%$ & 4.282 & $85.64 \%$ \\
\hline Protein & D & $2.0 \%$ & 4.2925 & $85.85 \%$ \\
\hline & A & $0.0 \%$ & $4 \% \mathrm{~N}$ & $2.55 \%$ \\
\hline & B & $0.5 \%$ & $4 \% \mathrm{~N}$ & $2.55 \%$ \\
\hline & C & $1.0 \%$ & $4 \% \mathrm{~N}$ & $2.55 \%$ \\
\hline & D & $2.0 \%$ & $4 \% \mathrm{~N}$ & $2.55 \%$ \\
\hline & A & $0.0 \%$ & 4.14 & $82.2 \%$ \\
\hline & B & $0.5 \%$ & 4.12 & $82.4 \%$ \\
\hline & C & $1.0 \%$ & 4.13 & $83.6 \%$ \\
\hline & D & $2.0 \%$ & 4.14 & $82.2 \%$ \\
\hline
\end{tabular}




\section{Rancidity}

All butter samples with different percentages of preservative were analysed for rancidity development over a period of 50 days (Table 3). The butter sample without addition of sodium chloride got rancid most easily than other samples giving a peroxide value of $5 \mathrm{meg} / \mathrm{kg}$. The butter sample with $0.5 \%$ sodium chloride also gave peroxide value of $2 \mathrm{meg} / \mathrm{kg}$ in last ten days of preservation, but this value of rancidity is unfavourable for butter consumption. The rest of two butter samples with $1.0 \%$ and $2.0 \%$ sodium chloride as preservative resisted rancidity giving zero peroxide value showing that these percentages of sodium chloride can preserve the butter even for two months. Therefore, it is concluded that for long-term consumption, butter can be preserved using at least $1 \%$ sodium chloride. For tradition and for scientific reasons people add herb extracts as antioxidants to butter oil for preventing the development of the peroxide value and conjugated diene in butter oil [20].

Table 3. Rancidity development

\begin{tabular}{|c|c|c|c|c|c|c|c|}
\hline \multirow{2}{*}{ Treatments } & NaCl & \multicolumn{7}{|c|}{ Rancidity (peroxide value) } \\
\cline { 3 - 8 } & $(\%)$ & 0 days & 10 days & 20 days & 30 days & 40 days & 50 days \\
\hline 1 & 0.0 & 0 & 0 & 0 & 0 & 0 & 5 \\
\hline 2 & 0.5 & 0 & 0 & 0 & 0 & 0 & 2 \\
\hline 3 & 1.0 & 0 & 0 & 0 & 0 & 0 & 0 \\
\hline 4 & 2.0 & 0 & 0 & 0 & 0 & 0 & 0 \\
\hline
\end{tabular}

\section{Conclusions}

From this research, it is concluded that the presence of sodium chloride as preservative in the butter prevents rancidity of the butter. It also contributes towards lowering of the moisture contents but increase in the solid contents and ash weight of the butter. It also maintains the integrity of butter's proteins and fats by preventing them from denaturation.

\section{Authors' contributions}

Conceived and designed the experiments: $\mathrm{S}$ Rashid \& AM Salariya, Performed the experiments: MU Raza \& S Kausar, Analyzed the data: A Arif \& MA Saleem Wrote the paper: JI Wattoo \& A Arif.

\section{References}

1. Uksila E \& Kurkela R (1968). Evaluation of the nutritional properties of some heated fats by animal experiments. Nutritio et dieta; European review of nutrition and dietetics 10(1): 45-53.

2. Lozano PR, Miracle ER, Krause AJ, Drake M \& Cadwallader KR (2007). Effect of cold storage and packaging material on the major aroma components of sweet cream butter. $J$ of agricultural and food chemistry 55(19): 7840-7846.

3. Swarna C, Prabha R \& Shankar P (1997). Effect of added lipases of psychrotrophic Yersinia, Enterobacter and Citrobacter spp. on the keeping quality of milk and fat rich milk products. Indian $J$ of animal sciences 67(7): 611-613.

4. Meyer DM, Garnett I \& Guthrie J (1997). A survey of dairy manure management practices in California. $J$ of Dairy Science 80(8):1841-1845.

5. Barui N \& Chanda S (2000). Aeromycoflora in the central milk dairy of Calcutta, India. Aerobiologi 16(3-4):367-372.

6. Viajayalakshmi $\mathrm{R} \&$ Murugesan $\mathrm{T}$ (2001). Shelf life and microbilogical quality of selected dairy products. $J$ of food science and technology 38(4): 385-386. 
7. Rady A \& Badr H (2003). Keeping the quality of cows' butter by $\gamma$-irradiation. Grasas y aceites 54(4): 410-418.

8. Povolo M \& Contarini G (2003). Comparison of solid-phase microextraction and purge-and-trap methods for the analysis of the volatile fraction of butter. $J$ of Chromatography A 985(1): 117-125.

9. Özcan M \& Ayar A (2003). Effect of propolis extracts on butter stability. Journal of Food Quality 26(1):65-73.

10. Ayar A, Özcan M \& Akgül A (2007). Effect of oregano and sage extracts on microbiological quality of molten butter. Food Science and Technology research 10(2): 111-113.

11. Kim J, Jung $\mathrm{T}$, Ahn $\mathrm{J} \&$ Kwak $\mathrm{H}$ (2006). Properties of cholesterolreduced butter made with $\beta$ cyclodextrin and added evening primrose oil and phytosterols. Journal of dairy science 89(12):4503-4510.

12. Ozturk S \& Cakmakci S (2006). The effect of antioxidants on butter in relation to storage temperature and duration. European J of Lipid Science and Technology 108(11): 951-959.

13. Ahmad S, Gaucher I, Rousseau F, Beaucher E, Piot M, Grongnet JF \& Gaucheron F (2008). Effects of acidification on physico-chemical characteristics of buffalo milk: A comparison with cow's milk. Food Chemistry 106(1): 11-17.

14. Idoui $\mathrm{T}$, Benhamada $\mathrm{N} \&$ Leghouchi $\mathrm{E}$ (2010). Microbial quality, physicochemical characteristics and fatty acid composition of a traditional butter produced from cows' milk in East Algeria. Grasas Y Aceites 61(3): 232-236.

15. Okullo JBL, Omujal F, Agea J, Vuzi P, Namutebi A, Okello J \& Nyanzi S (2010). Physico-chemical characteristics of Shea butter (Vitellaria paradoxa CF Gaertn.) oil from the Shea district of Uganda. African $J$ of Food, Agriculture, Nutrition and Development 10(1).

16. Riel R (1963). Physico-Chemical Characteristics of Canadian Milk Fat. Unsaturated Fatty Acids. J of Dairy Science 46(2): 102-106.

17. Robards K, Kerr AF \& Patsalides E (1988). Rancidity and its measurement in edible oils and snack foods. Review. The Analyst 113(2): 213-224.

18. Gandhi K, Kumar A \& Lal D (2015). Iodine value integrated with solvent fractionation technique as a tool for detecting palm olein and sheep body fat adulteration in ghee (clarified milk fat). Indian J of Dairy Science 68(4).

19. Wasnik PG, Menon RR, Surendra Nath B, Balasubramanyam BV, Manjunatha M \& Sivaram, M (2017). Application of particle analysis and colour parameters for detection of adulteration of cow ghee with vanaspati derived from image analysis. Indian J Dairy Sci 70:2.

20. Pawar N, Gandhi K, Purohit A, Arora S \& Singh RR (2014). Effect of added herb extracts on oxidative stability of ghee (butter oil) during accelerated oxidation condition. $J$ of Food Sci and Technology 51(10): 2727-33. 